\title{
Matal oko Geothermal Power Plant Development Strategy In Order To Maintain The Sustainability Of Supply And Demand Electric Energy In Kupang, East Nusa Tenggara (A System Dynamics Framework)
}

\author{
Addin Aditya ${ }^{1 *}$ \\ ${ }^{1}$ Department of Information System, Sekolah Tinggi informatika dan Komputer Indonesia, Jl. Raya Tidar No. 100 Malang 65149, Indonesia \\ * Corresponding author : addin@stiki.ac.id \\ Tel.: +6282335137337 \\ Received: July 28, 2017. Revised : Aug 4, 2017, Accepted: Aug 5, 2017, Published: 1 Sept 2017 \\ DOI : 10.24273/jgeet.2017.2.3.488
}

\begin{abstract}
One of Indonesia's problem as an archipelagic country is unequally electrification ratio, especially in Indonesia eastern region. In 2015, the electrification ratio in Kupang is $58.67 \%$ This figure is far below from Indonesia electrification ratio, which is $88.3 \%$ At present, people of Kupang get their electricity supply from fuel energy power system, which is costly and has a bad impact for environment. Furthermore, Indonesia has many renewable resource that has not been fully utilized and this condition in line with acceleration program of electricity infrastructure development in Indonesia, considering that Kupang has a geothermal potential in Mataloko. This research aims to develop a dynamical model of Mataloko geothermal power plant $1 \times 2.5 \mathrm{mw}$ development strategy in Kupang, East Nusa Tenggara from technical and economical aspect. We used system dynamics to modelling the existing electricity condition in Kupang as a base model to develop scenarios. We hope this scenario can betaken as consideration to develop a renewable resource power plant in order to fulfill the electricity demand. The result shows that geothermal potential in Mataloko is feasible to generate an electricity.
\end{abstract}

Keywords: Geothermal Power System, Renewable Resource, Electrification Ratio, Supply and Demand, System Dynamics

\section{Introduction}

Electricity energy has become a primary needs for all people in Indonesia. In line with the rapid growth of economics, industrial and information technology, then electricity demand will raise (Rahawuryan, et al., 2015). Nowadays, Indonesia has unequal electrification ratio caused of production of electricity was not enough to fulfill the demand.

East Nusa Tenggara is an archipelago province with 1.192 number of islands, 432 islands with name and 44 inhabitants island. Big islands in NTT usually called Flobarmorata (Flores, Sumba, Timor, Alor and Lembata). The area of NTT is $47.931,54 \mathrm{~km}^{2}$. Administrative area of NTT divided to 21 regency and 1 city. The largest area is Sumba Timur regency with $7.005 \mathrm{~km}^{2}(14.61 \%$ and Kupang Regency with $5,525.83 \mathrm{~km}^{2}(11.53 \%$. The smallest area in NTT is Kupang City with $180.27 \mathrm{~km}^{2}(0.38 \%$ and Sabu Raijua Regency with $460.47 \mathrm{~km}^{2}$ (0.96\%). Astronomically, NTT province is located between $8^{\circ}$ $-120^{\circ}$ south latitude and between $118^{\circ}-125^{\circ}$ east latitude. In terms of geographic position, NTT province has boundaries as follows: North - Flores Sea, South - Indian Ocean, West - Nusa Tenggara Barat, East-Timor Leste (BPS_NTT, 2016).
At present, the electrification ratio of East Nusa Tenggara is $58.67 \%$ This figure is still far below the Indonesia electrification ratio, which is $88.3 \%$ Indonesia's government has an acceleration program of 35,000 mw electricity development and Kupang has a renewable resource that in line with it. We hope with the existence of this geothermal energy, can fulfill the electricity demand of Kupang and also increase the electrification ratio in it.

\section{Basic Theory}

\subsection{Geothermal Energy}

Geothermal energy is energy contained within the high temperature mass of the earth crust, mantle and core (Toth \& Bobok, 2017). Since the earth interior is much hotter than its surface, energy flows continuously from the deep, hot interior up to the surface. This is the so-called terrestrial heatflow. The temperature of the earth's crust increases with depth in accordance with Fourier's of law of heat conduction. Thus the energy content of a unit of mass also increases with depth.

Nowadays, geothermal energy production is mainly achieved from hot water steam production via boreholes. Another rapidly growing production 
technology involves exploiting the energy content of near-surface regions by using shallow boreholes heat exchangers and heat pumps. It is likely that the natural heat of volcanoes and other geothermal resource were already being used in the remote of Paleolithic era, but concentrate evidence only 8000 to 10000 years ago. We are therefore forced to use indirect methods when speculating on mankind's earliest relationship with geothermal phenomena and products of the earth's heat.

The geothermal field is a geographical notion designating any region on the earth's surface where such surface manifestation as geysers, fumaroles or boiling mud-ponds indicate an active geothermal domain underground. These phenomena are characteristic of active volcanic regions. Where geothermal fields exist but have no spectacular surface manifestation, high terrestrial heat-flow and above-average geothermal gradient show that geothermal energy production would still possible (Boldizàr, 1943).

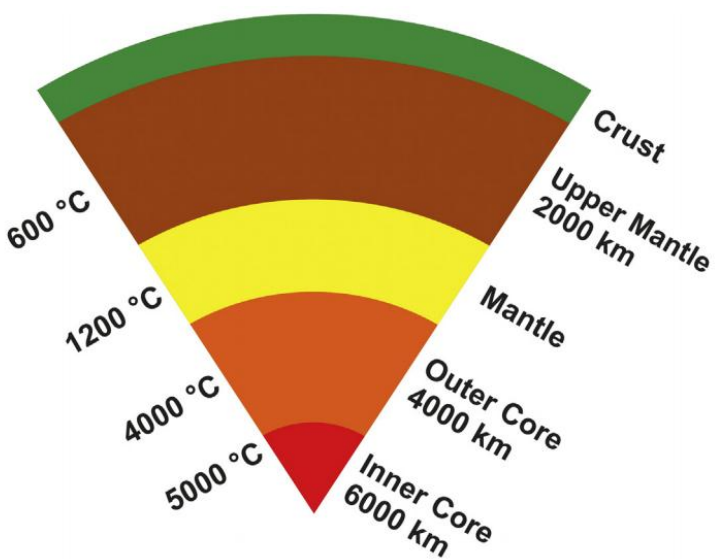

Fig 1. Structure of Earth's Interior (Toth \& Bobok, 2017)

\subsection{Geothermal Power Plants}

Principally, the work of geothermal power system is same as steam power plant, only steam power plant using boiler to make a steam while steam for geothermal power plant was from geothermal reservoir (Hanindhito, et al., 2011). Geothermal power plant development method were divided in three ways:

1. Dry Steam Power Plant

This is the first method to develop geothermal power plant. Steam from geothermal resource run directly by pipes that connected with generator. Then hot steam from steam turbine is cooled in condenser unit and after that it injected to the geothermal reservoir.

2. Flash Steam Power Plant

Steam from geothermal resource is separated from water particle in separator unit. Hot steam will flow to turbine for spin it. After that, temperature of steam will decreased through direct contacts condenser or heat exchanger type condenser. Mainly steam will turn into water and injected to the geothermal reservoir or can be used to another needs.

3. Binary Steam Power Plant

This method will be implemented if fluid temperature of geothermal is in low level. Fluid from geothermal resource ran directly to exchanger unit that will heat up the organic fluid until it produce steam. This steam will be used to spinning the turbine that connected with generator. After it used to spinning the turbine, steam will turns into fluid element and it used to exchanger unit again. Fluid from geothermal resource through exchanger unit will be injected to the geothermal reservoir after cooling process.

\subsection{Model and Simulations}

Model is a represent from the real system. It called good model if its behaviors mostly represent the system in the real world with no breaking the basic rules of system thinking. Building a model is influencing by person subjectivity or organizations, then we need perfection to do continuously with digging a relevant potential and information (Winardi, 1989).

There are several advantages using modelling in research with system approach (Barlas, 1996), such as:

1. Allow us to do many kind of research without limitation of research areas

2. Allow us to do experiment to system without breaking the real system

3. Could determining the objectivity of maintenance system activity

4. Can use to predicting the next behavior and condition system

To develop system dynamics model, firstly we understand system with it problems and connecting each other so it will make a loop / causal Ioop (Suryani, 2006)

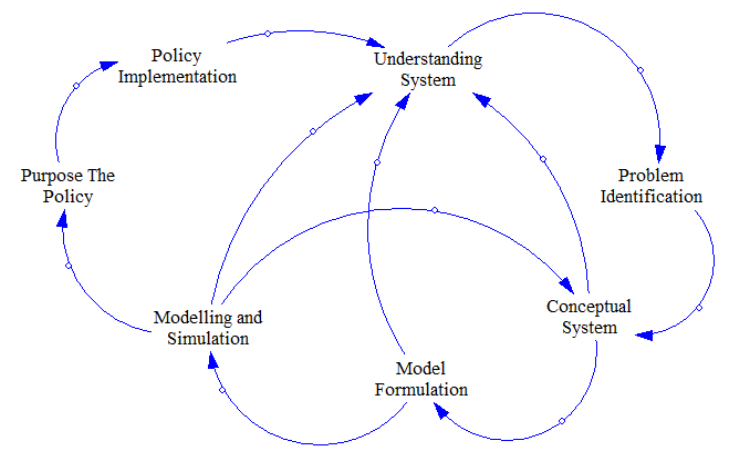

Fig. 2. Modelling Research Problem with System Dynamics

Commonly, modelling research with system dynamics using special software. Such as vensim, powersim, stella and dynamo. A model can be made 
with drawing variables and its connection through those software. Structure and behavior will be important things that must concern to building system dynamics models. Structure is an element that forming a phenomena. Relevancy between elements (see Fig 3) are depended by:

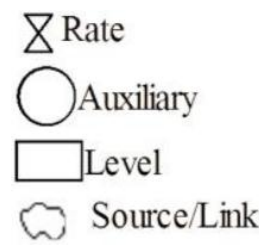

Fig 3. Variables in System Dynamics

Level define as a condition in system every several times. Level is accumulation in a system. Equation in rate variable is decision structure that explain how and why a decision made based on information system. Auxiliary is formulation from variables to fulfill stock and flow. Source is components that has no related with system.

To ensure that model represent the real system, validation is necessary (Forrester, 1968). There's two ways to measure model validity:

a. Mean Comparison

$$
E 1=\frac{|\bar{S}-\bar{A}|}{\bar{A}}
$$

Where:

$\mathrm{S}=$ Mean of Simulation

$\mathrm{A}=$ Mean of Data

Model valid if E1 $\leq 5 \%$

b. Error Variance

$E 2=\frac{S s-S a}{S a}$

Where:

Ss $=$ Standard Deviation of Model

$\mathrm{Sa}=$ Standard Deviation of Data

Model valid if E2 $\leq 30 \%$

\section{Data and Methods}

\subsection{Data}

All data in this research obtained through survey and interview with PT PLN (Persero). In addition, books and journals review is necessary to adding some information about geothermal energy. Also data number of electricity customer, number of household and geographical condition from Statistic Center (BPS). These data will formed to model so that can be a basic model to determining policy scenarios. Several data that accomplish to collect is:

1. Data of NTT electricity customer

2. Data of NTT Peak Load
3. Electricity demand growth

4. Geographical condition of Mataloko field

\subsection{Conceptual Model}

Next step is building a conceptual model. In terms of system dynamics, conceptual model often called as causal loop diagram. This diagram represent variables that related each other and it forming a loop diagram (Fig 4).

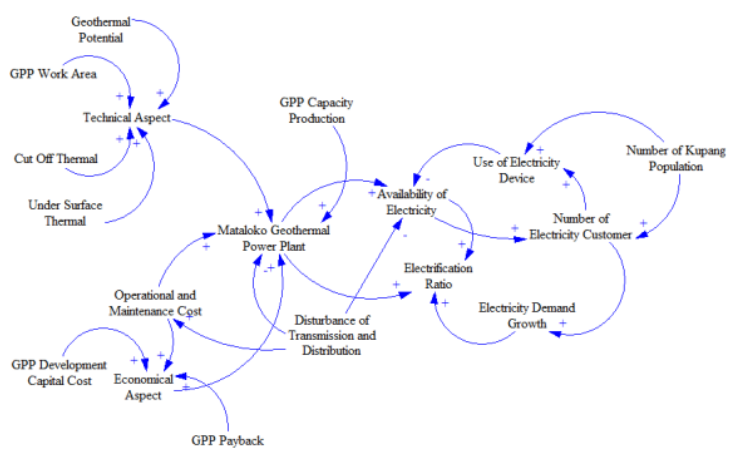

Fig 4. Causal Loop Diagram

\section{Result and Discussion}

\subsection{Base Model}

Firstly, to build base model we need to identify what kind of variables that related to the main system. In this case, electricity demand and rate of demand are main variable that influence the electrification ratio in NTT (Fig 5).

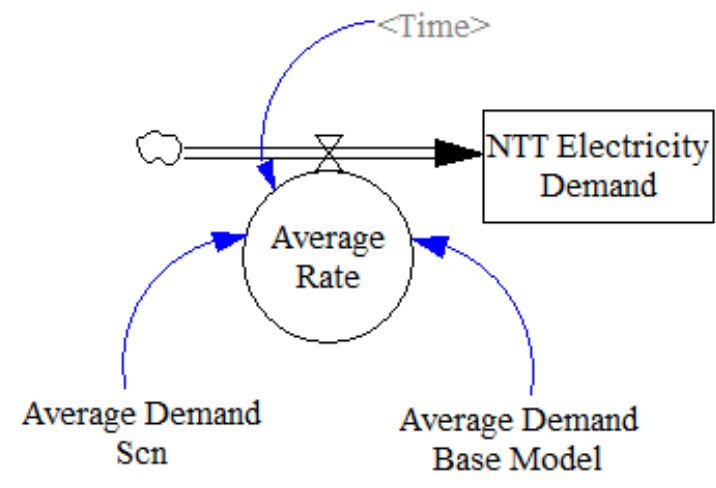

Fig 5. Base Model of Electricity Demand

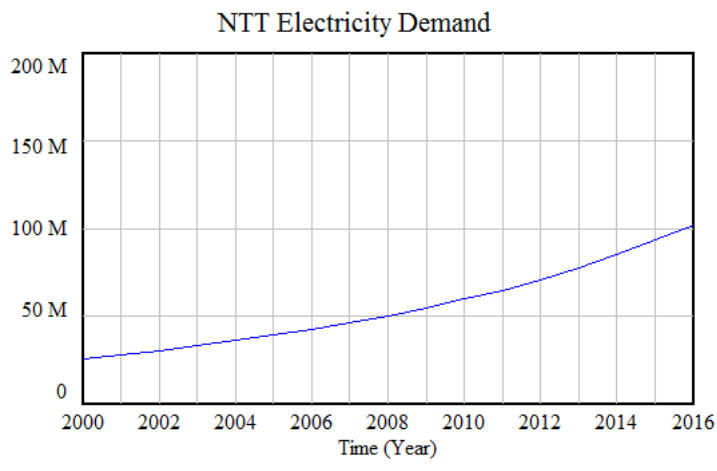

Fig 6. Simulation Result of NTT Electricity Demand 


\subsection{Validation}

Validation to base model is necessary with using mean comparison and error variance. The result shows that base model is already represent the real system (Table 1).

Table 1 Validation of Base Mode

\begin{tabular}{ccc}
\hline Variable & Valid E1 $\leq \mathbf{5 \%}$ & $\begin{array}{c}\text { Valid E2 } \leq \\
\mathbf{3 0 \%}\end{array}$ \\
\hline $\begin{array}{c}\text { NTT Electricity } \\
\text { demand }\end{array}$ & $1 \%$ & $7 \%$ \\
\hline
\end{tabular}

\subsection{Model Scenario}

There are two ways to build a model scenario, parameter scenario and structure scenario. In this case will use structure scenario, which is adding some model scenario. Such as capacity planning sub model, fulfillment ratio sub model, power plant utilization and economical aspect sub model.

\subsubsection{Power Plant Capacity Planning}

There are several factors that must be concerned to modelling power plant capacity. Such as, total of electricity demand in an area and reserve margin. Reserve margin is power spare of power plant to peak load and represent by percent $(\%$. Based on electricity demand in Fig 5 and add reserve margin about 20\% (PLN, 2016) then sub model of power plant capacity planning can be built. From the result of simulation can be seen that need $86.4 \mathrm{mw}$ fulfill the electricity demand in NTT province.

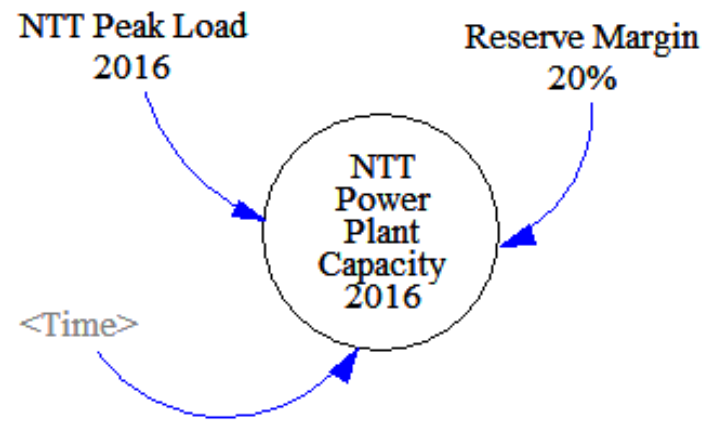

Fig 6. NTT Power Plant Capacity Planning

\subsubsection{Technical Aspect of Geothermal Power Plant}

This model built in order to identify what kind of variable that have to be concerned in planning and developing geothermal power plant and estimating how much power that can be produce to fulfill the electricity demand.

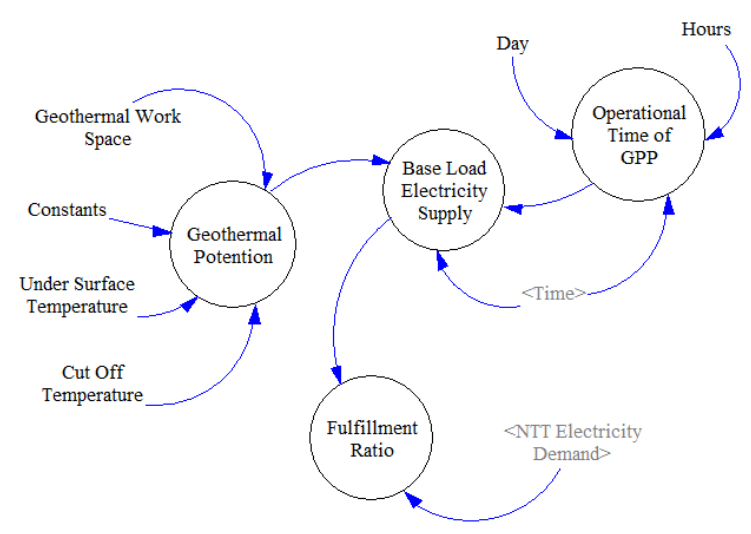

Fig 7. Fulfillment Ratio of Geothermal Power Plant

Variables that has to be concerned in order to develop geothermal power plant is geothermal work space, constants, under surface temperature and cut off temperature (Tama, 2012). Here is the equation model of geothermal potential:

$\mathrm{Q}=0.115858 * A *\left(\mathrm{~T}_{\text {Res }}-\mathrm{T}_{\text {cut off }}\right)^{\circ} \mathrm{C}$

With:

Q : Geothermal potential (Mwe)

A : Geothermal Work Space $\left(\mathrm{Km}^{2}\right)$

$\mathrm{T}_{\text {Res }}$ : under surface temperature $\left({ }^{\circ} \mathrm{C}\right)$

$\mathrm{T}_{\text {cut off }}$ : cut off temperature $\left(120^{\circ} \mathrm{C}\right)$

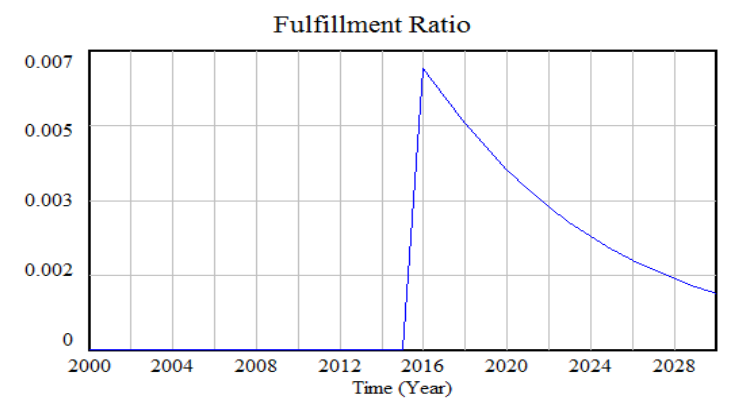

Fig 8. Simulation Result of Geothermal Power Plant Fulfillment Ratio

\subsubsection{Geothermal Power Plant Utilization}

Utilization is the primary method by which asset performance is measured and business success determined. In power plant development, utilization is necessary to calculating how much the utilization of geothermal energy to meet the electricity demand in a region. This following picture shows a model scenario of power plant utilization. From the simulation result shows that in 2030 , the utilization of geothermal power plant is $75 \%$ 


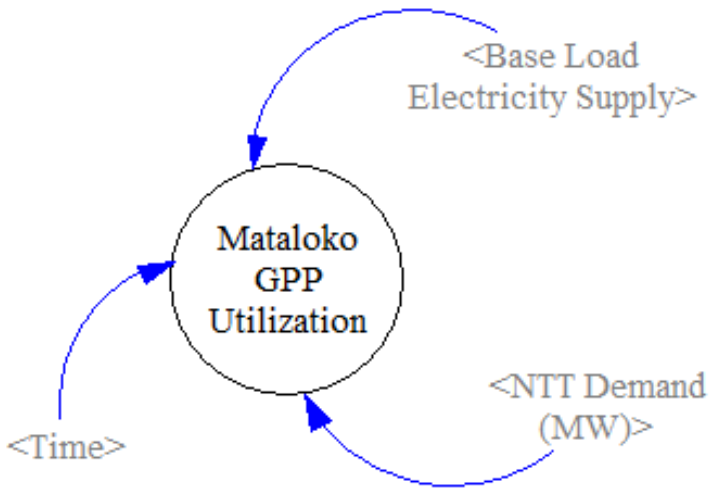

Fig 9. Model Scenario of Power Plant Utilization

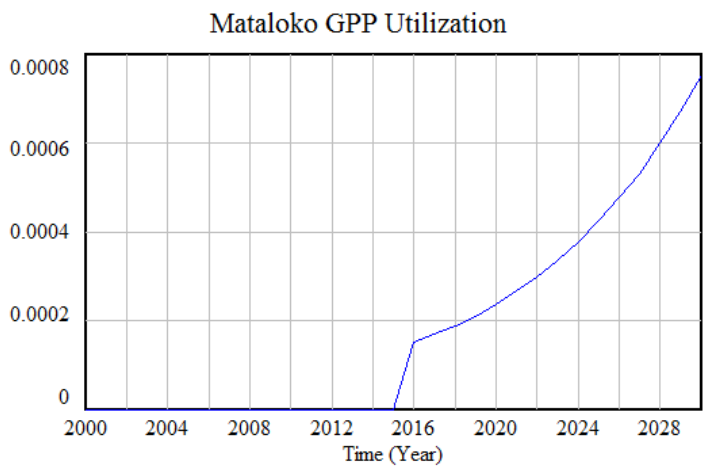

Fig 10. Simulation Result of Power Plant Utilization

\subsubsection{Power Plant Economical Aspect}

In developing of geothermal power plant is determined by investment cost. Such as wells exploration, wells injection, wells production and wells make up (Santoso, 1997). And also pi ping cost, operational and maintenance cost and separator. Investment cost of geothermal power plant development is IDR $139,039,920,000$. Here's the detail of geothermal power plant development investment.

Table 2. Cost Description of Power Plant Development (PLN)

\begin{tabular}{ccc}
\hline No & Description & Cost (IDR) \\
\hline 1 & $\begin{array}{c}\text { Wells Exploration } \\
\text { Cost }\end{array}$ & $95,889,600,000$ \\
\hline $\mathbf{2}$ & Wells Injection Cost & $19,977,000,000$ \\
\hline 3 & $\begin{array}{c}\text { Operational and } \\
\text { Maintenance }\end{array}$ & $23,173,320,000$ \\
& total & $139,039,920,000$ \\
\hline
\end{tabular}

Based on table 2 and calculation on fig 11 then can be concluded geothermal development payback time is 16 years and income projection per year is IDR 731,727,424.

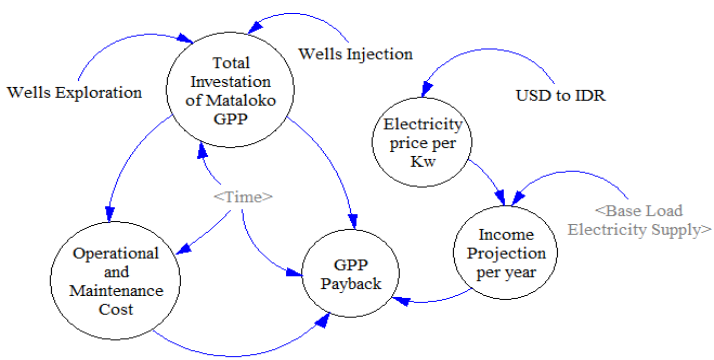

Fig 11. Economical Aspect of Geothermal Power Plant Development

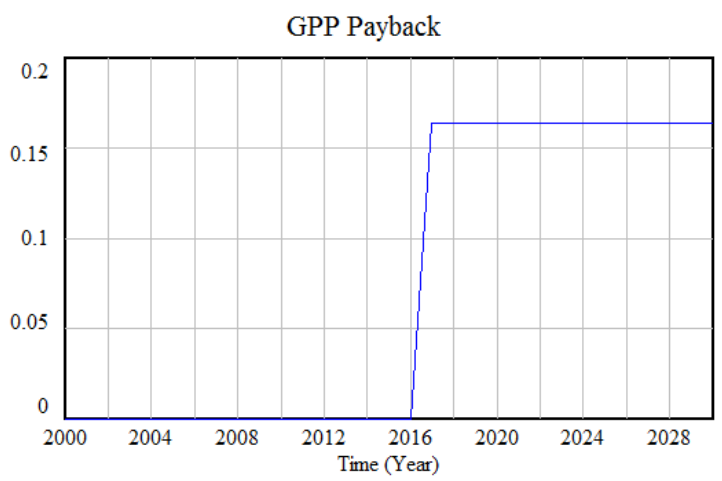

Fig 12. Simulation Result of Geothermal Power Plant Payback

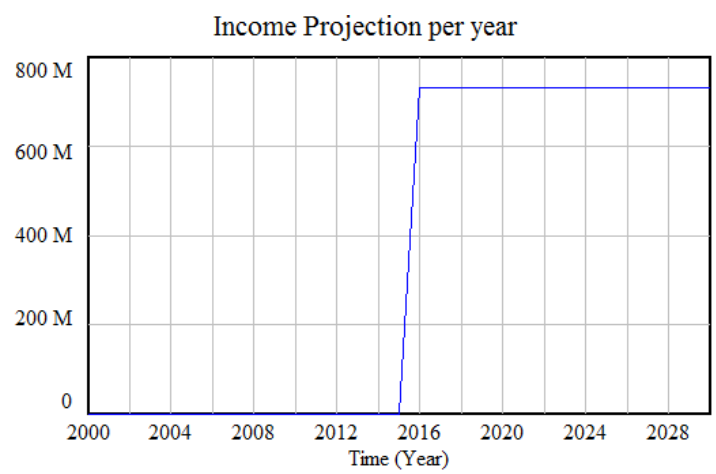

Fig 13. Income Projection per Year of Geothermal Power Plant Development

\section{Conclusions}

In this research can be concluded that:

1. Geothermal power plant development planning is very necessary in order to ensure the sustainability of electricity supply and demand in NTT. Furthermore, this research is also support the government program in using renewable resource as a main energy.

2. Technical aspect that must to be concerned in developing geothermal power plant are geothermal workspace area, under surface temperature and cut off temperature.

3. Payback time of geothermal power plant investment is 16 years after it operation. Based on this results are proven that mataloko field is feasible to develop a power plant. 


\section{References}

Barlas, Y., 1996. Multiple Test For Validation os System Dynamics Type of Simulation Model. Turkey: s.n.

Boldizàr, T., 1943. Aspect of Geothermal Gradient in Mining Industry (In Hungarian). Budapest: BKL 20.

BPS NTT, 2016. Nusa Tenggara Timur Province in Figures. Nusa Tenggara Timur: BPS-Statistics of Nusa Tenggara Timur.

Forrester, J. W., 1968. Principle of System. Massachusettss: Wright-Allen Press Inc..

Hanindhito, S., Mahmudsyah, S. \& Yuwono, T., 2011. Studi Pembangunan PLTP Guci 1 x 55 mw Jawa Tengah Berdasarkan Aspek Teknis, Ekonomi dan Lingkungan.

PLN, 2016. [Online] Available at: http://www.pln.co.id

Rahawuryan, F., Marsudi, S. \& Purwati, E., 2015. STUDI KELAYAKAN PERENCANAAN PLTA KESAMBEN KABUPATEN BLITAR JAWA TIMUR, S.l.: S.n.

Santoso, P., 1997. KAJIAN KEEKONOMIAN DAN KEBIJAKAN PENGUSAHAAN SUMBER DAYA ENERGI PANAS BUMI UNTUK PEMBANGKITAN LISTRIK SKALA KECIL DI INDONESIA.

Suryani, E., 2006. Pemodelan dan Simulasi. Yogyakarta: Graha IImu.

Tama, R. G., 2012. STUDI PENGEMBANGAN PEMBANGKIT LISTRIK TENAGA PANAS BUMI (PLTP) DI JAILOLO UNTUK MEMENUHI KEBUTUHAN LISTRIK DI MALUKU UTARA. Proceeding Seminar Tugas Akhir Jurusan Teknik Elektro FTI-ITS.

Toth, A. \& Bobok, E., 2017. Flow and Heat Transfer in Geothermal Systems. Miskolc: elsevier.

Winardi, 1989. Pengantar Tentang Teori Sistem dan Analisis Sistem. Bandung: Mandar Maju. 